\title{
5 \\ Contradictions in implementing performance management
}

\author{
John Halligan
}

Performance has been a leitmotif of the reform era and the centrepiece of managerialism in Anglophone countries. Its pervasive influence has dictated the operations of government departments (Bouckaert and Halligan 2008; Radin 2006). It is impossible to envisage public management without regard to results, targets and performance measurement. However, a paradox of performance has been that the information generated for management frameworks has been often unused. The tension between the managerial and the political purposes of performance management has been a continuing dynamic of the reform era, which is one reason why the design of performance systems remained unresolved (Halligan 2020).

The performance movement shifted the focus from inputs and processes to outputs and outcomes, or more generally results. The underlying proposition was deceptively simple: to establish a process for advancing objectives with the promise of measurement and accountability, and then reporting results against indicators. There were, however, complications, for purposes were not always clear and often competing, their relevance varied with stakeholders (Behn 2003) and different logics were in play (Pollitt 2013; Gill 2011b). The practice was also demanding, as it entailed the intricacies of performance measurement and reporting, leading to 
complex interactions with politicians about the results. Given the pitfalls, it was not unexpected that the efficacy of performance management was mixed.

The Anglophone countries (Australia, Canada, New Zealand and the United Kingdom) were more committed at an early stage in the reform era to performance management and measurement than most Organisation for Economic Cooperation and Development (OECD) countries (OECD 1995; Bouckaert and Halligan 2008). This level of commitment has continued for over three decades, during which the countries have reworked their measurement and performance frameworks and expanded the range of performance instruments. There were variations in approaches to the common arrangement for all departments - the whole-of-government performance framework - and the use of specific performance instruments for measuring efficiency or tracking progress against targets. The countries' distinctive pathways allow comparisons of approaches to managing performance systems, the clusters of instruments used and lessons from the constant redesign of frameworks. Questions are raised as to whether progressive development has occurred with the core framework and the performance system and reported limitations of a performance approach have been addressed.

\section{The purposes and instruments of performance}

Several purposes have been differentiated for performance information (Van Dooren, Bouckaert and Halligan 2015), but essentially there are five: public accountability, central control, management improvement and learning, business planning and strategy, and results or priorities. The last three have assumed greater centrality for several countries. It can be argued that the standard purpose has always been about performance and therefore results, but these are subject to different interpretations and practice.

Performance measures can be used for multiple purposes (Behn 2003; Gill and Schmidt 2011; Van Dooren, Bouckaert and Halligan 2015), but the extent to which more than one (or two) can be appropriately achieved simultaneously through measuring information can be problematic. Much depends on the degree of clarity and understanding 
of the accountabilities, the handling of multiple stakeholders and the complexities of attending to several purposes. The primary purpose of a performance instrument has been first and foremost about reporting, of putting on the record what has been done; in other words, accounting against intentions. Or is it about attaining progress on an activity, which is then documented through measurable results? If the first, it leans towards accountability, and at worst becomes a matter of compliance and retrospectivity. If the latter, it may be primarily focused on achieving a government agenda. Of course, it may purport to be about both, and have other purposes.

The solution under the standard logic model has been that outcomes will provide the effects or results. Outcomes are however subject to two primary difficulties that often seem insurmountable: first, articulation and application (credible measurement), a constant problem being consistency in applying an outcomes approach; the second is about accounting for achievements where there are factors that cannot be controlled for. This has led to a focus on intermediate outcomes in the language of results. There are well-established understandings about the weaknesses of performance management (Radin 2006), and major issues have also arisen with the unintended consequences of performance assessment at the delivery level.

Performance is multifaceted and extensive. The focus here on the organisational and systemic performance of the central government raises two considerations. First, in demarcating the performance system, much performance activity is excluded: the macro or whole-of-government level is central, as is the meso level (performance of joint activity) and to some extent the micro level (the department). An understanding of cases (Gill 2011a), and factors affecting performance at this level, form one basis for generalisations. Secondly, different instruments have been used for judging performance, ranging from the general framework for departments to specific and highly focused tools.

The generic performance management framework is conceived in different ways depending on what is expected of it (e.g. a strategic framework: NAO 2016), but the core element is the parliamentary estimates (or plan) and annual reporting. While the focus is on the overarching performance framework, other specialised instruments of performance have been recognised, and six are identified here: implementation in furtherance of government priorities, chief executive assessment, organisational capabilities, efficiency, corporate planning and program evaluations. These 
may be either ad hoc or ongoing, published or unpublished (the latter not being of demonstrable public significance), or hybrids (either largely unpublished or opaque to the public and of questionable value). Departmental head reviews are private, although the integrity of the system depends on the clarity of the assessment criteria and the process. Results can be either integrated with the performance management framework or form an 'overlay' of government objectives.

In order to consider the focus and role of the country frameworks, five dimensions are derived from the literature and official documents (Table 5.1). The first is the degree of focus or spread of the purposes (ranging from the basics to a comprehensive 'road map'). The significance of planning and whether it has been used internally by departments is relevant here. Also important is the political executive's role and the centrality of its priorities (which are also related to ownership of the framework, either by one or two central agencies). A corollary of these last two is the question of the range and relative importance of stakeholders (Talbot 2008). Third is the question of whether the framework has been stable and durable across governments (NAO 2016). The cross-cutting component is the fourth element. Finally is the question of whether evaluation is built into performance management (Talbot 2010).

\section{Performance management frameworks: How have countries handled them?}

The core of the performance system has been the performance management framework for departments and agencies. The four countries detailed below have had a fully-fledged model that fitted within the 'performance management' ideal type differentiated by Bouckaert and Halligan (2008). The official model has usually been based on an outputs and outcomes framework that covered organisational dimensions and their management interrelationships. Their frameworks have been pursued in some form since the 1980s and have provided the longest records of most OECD countries - an exception being the US - in wrestling with how to make performance management work. 


\section{Australia: Path dependence}

The Australian agenda since the mid-1980s has involved three phases, each initiated by a new performance framework: the first dating from the inauguration of a new system (1986); the second from its reformulation (1997-99); and the third implemented in 2014-16. The first two frameworks reflected two reform phases: managerialism and the new public management variant (Halligan 2007a). In the first, the elements of performance management were developed through the Financial Management Improvement Program. The focus on results, outcomes and performance-oriented management dates from this time (Wanna, Kelly and Forster 2000). The core was program budgeting and management, which was to assist managers' assessments of program development and implementation relative to objectives. All programs had to be reviewed every five years and departmental evaluation plans produced annually for the Department of Finance (Campbell and Halligan 1992; Keating and Holmes 1990; TFMI 1993). In this phase, the elements of performance management were developed within a centralised approach. The strengths were institutionalised performance management and the experience of formal evaluations by the centre. The weaknesses were the quality of objectives for, and performance information on, programs.

The second formulation was based on an outcomes/outputs framework, devolution, principles instead of formal requirements and an emphasis on performance information. Departments and agencies were required to identify explicit outcomes, outputs and performance measures, and their heads were assigned responsibility and accountability for performance. However, problems with the design and implementation became apparent, and a succession of piecemeal interventions occurred, which failed to prevent a continuing critique. Departmental programs were reincorporated because ministers argued they lacked the information required for making decisions. Even where a principle-based approach was used, controls were reimposed in the form of inputs and 'front-end processes'. The framework became more compliance-focused and less about performance and achieving results (DFD 2012, 34). A succession of studies by the audit office and a ministerial review, Operation Sunlight, raised serious questions about the efficacy of aspects of the framework and the need for renewal (e.g. Tanner 2008; ANAO 2011; Hawke 2012). There were strengths, such as strong ownership for departments. Weaknesses included insufficient information for parliamentary needs 
and sound management (Mackay 2004), weak support for evaluation and problems arising from combining a centralised budgetary process with devolved departments.

After 30 years, Australia still lacked an effective system (ANAO 2011, 2013; Halligan 2007b; Hawke and Wanna 2010; Mackay 2011; Tanner 2008). The framework was the subject of a multi-year review by Finance (DFD 2012; DoF 2014). Under the Public Governance, Performance and Accountability Act 2013 (Cth), a new framework was implemented with outcomes and programs retained. It was intended to resolve limitations, to report more effectively and to integrate departmental planning and performance management, using corporate plans, plus other aspirations, such as improved risk management. An initial survey reported that notable challenges remained, including overcoming risk aversion and improving performance (DoF 2015; Podger 2015). The third framework was a progressive development (Hawke 2016), but the quality of reporting on performance information still required improvement. In key areas such as management of risk and cross-government cooperation - little had changed (Alexander and Thodey 2018).

\section{Canada: Confronting conundrums}

Canada's pathway is notable for an early succession of trials and acknowledged failures, followed by a gestation period before a fullyfledged and durable performance management framework was installed in the 2000s. This was then somewhat overtaken by the 'results and delivery' agenda in the late 2010s.

The shift from structuring the main estimates as a traditional program budget occurred after 1995 with the introduction of the Planning, Reporting and Accountability Structure (PRAS). Departments and agencies reported on their plans and priorities in the main estimates to inform parliament about the outputs and outcomes they wanted to achieve. There were issues with the quality and coverage of financial and performance data and the lack of outcomes focus. Assessments of departmental performance reports showed a limited focus on outcomes (Bouckaert and Halligan 2008).

By the mid-2000s, these issues had been responded to, if not convincingly addressed in practice. The Management Accountability Framework (MAF), was introduced in 2003, and the Management, Resources and 
Results Structure (MRRS) replaced PRAS as the basis for departmental reporting. A standardised approach was used to incorporate performance information in management and policy cycles. The MRRS established the link between results and programs connected with departmental management and structure. The requirements for departments were codified and integrated through reports on plans and priorities and departmental performance, which were designed to indicate the links between plans, performance and achievements. There was a shortage of independent analysis, and scepticism existed about performance management and the mandatory federal agenda (Clark and Swain 2005; Thomas 2004). The approach was heavily top-down, featuring central agencies, particularly the government's 'management board', the Treasury Board Secretariat. Nevertheless, by the mid-2000s, Canada had a developed performance management framework, which continued to evolve and be refined, and readily fitted within the 'performance management model' (Bouckaert and Halligan 2008). The MAF created a broader framework to anchor the performance focus by providing deputy ministers with tools to assess and improve management practices.

The Policy on Results supplanted MRRS in 2016 with the purpose of improving the attainment of results. Departments were expected to be clear about objectives and the measurement of success, and to measure and evaluate performance and use the information for managing and improving programs (Lindquist 2017).

\section{New Zealand: Escaping the constraints of the original model}

A key feature of the financial management reforms of the late 1980s was the distinction between outputs and outcomes, and their assignment respectively to chief executives and ministers. Under New Zealand's Public Finance Act, departments acquired responsibility for financial management from the Treasury. Chief executives managed inputs to produce outputs that ministers purchased. The focus was on chief executives and their responsibilities for managing departments under contract, as specified through performance and purchase agreements, and the annual assessment of their performance by the State Services Commission (Boston et al. 1996; Scott 2001). 
New Zealand was slow to tackle weaknesses of the model in the areas of accountability, performance measurement and strategic management. Two limitations were the emphasis of the output orientation on managerial accountability at the expense of public and parliamentary accountability, and gaps in the system's capacity to learn from experience. The link between outputs and desired outcomes was variable because of how the political executive engaged: ministers were expected to utilise the connection and set performance targets (Boston et al. 1996; Schick 1996; Scott 1997; Kibblewhite and Ussher 2002). To address long-term strategic thinking, managing for outcomes was implemented through statements of intent (SOIs). Incremental improvements occurred in the quality of departmental planning, but most SOIs did not show much improvement (CAG 2006), and there was a need to refine output and outcome indicators and improve the links between them. The focus on performance was also applied to a broad agenda for better overall performance of the state services and development goals.

The focus on outputs and chief executive responsibility for delivering goods and services produced distortions, while ministers let their purchaser role override their responsibility for outcomes (Schick 2001). The system addressed outcomes conceptually but had problems integrating them into public management because of difficulties both in specification and in measurement (Kibblewhite and Ussher 2002). Performance information was not used much in the budget process, and the effectiveness of annual budgeting for assessing public performance was questioned (Shand and Norman 2005). Changes were difficult, because removing the output focus 'would strip the system of its magnificent conceptual architecture' (Schick 2001, 2).

The Public Finance Act 1989 was amended in 2013 to require agencies to address meaningful and useful performance measures for reporting externally. Agencies must still describe and evaluate performance, but Treasury prescriptions are more flexible and allow agencies to specify how performance is to be assessed. A turning point was the report of the Better Public Services Advisory Group, which stipulated improved performance by the state services by 'securing the outcomes that matter most to New Zealanders' wellbeing'. The system's strength, service delivery (outputs), was insufficient because, performance was not 'gaining traction on the big outcomes that matter' (BPSAG 2011, 14, 15). The report led to extensive activity centred on 10 result areas, and government prioritising ensured 
progress on targets (Morrison 2014; Scott and Boyd 2017). The 2019 budget has been produced on a wellbeing basis (James 2019), and the 2019 reform process is intended to support higher performance.

\section{United Kingdom: System churn - governing without a framework?}

The Financial Management Initiative was designed to focus on objectives and measure outputs and performance but was only partly successful. Outputs and service delivery became important from the late 1980s, and outcomes in the late 1990s (Bouckaert and Halligan 2008). The last decade has been notable for a succession of frameworks.

The political executive's drive for performance, delivery and results was relentless and reflected in instruments for aligning government priorities with progress in implementation. A turning point was when the performance framework, Output and Performance Analysis (OPAs), introduced in the mid-1990s, was replaced by Public Service Agreements (PSAs). The OPAs provided continuity with previous systems but were unaligned with key election pledges and omitted targets for measuring improvements (Panchamia and Thomas 2014). The PSAs were linked to spending reviews, which examined resources for each field of expenditure and the related service delivery in order to integrate a multi-year policy perspective with a budgetary process. Further spending reviews occurred mainly at two- or three-year intervals. Each department had a PSA, a two-yearly agreement with Treasury consisting of an aim, objectives, performance targets, value-for-money targets and a responsibility statement. They were operationalised through plans for reaching targets with reporting to the Cabinet Office and Treasury on implementation. The PSA was a novel instrument for bringing central government under a performance framework, but limitations included frequent changes to targets, unclear objectives and weak incentive effects on priorities (James 2004). Treasury made limited use of departments' performance reports (Talbot 2010). The PSA evolved, and was simplified (fewer PSAs and targets), enhanced (joint targets), and linked to spending reviews.

Departmental business plans (DBPs) were introduced by the Cameron Coalition to provide democratic accountability and to hold departments centrally accountable for implementing the reform program. Each plan addressed the coalition's priorities and program for the department, focusing on areas that the government could control in contrast to 
'aspirational outcomes' (Stephen, Martin and Atkinson 2011). Issues about usability were apparent, including ambiguity with the data, format inconsistencies, and difficulties with accuracy, analysis and comparability (Institute for Government 2011). There was no evidence that plans were being used by the Cabinet Office or ministers (Institute for Government 2012). For many departments, the business plans were unserviceable for measuring performance (Bull et al. 2013).

The DBPs were replaced in 2015 by a new business planning and performance management system, Single Departmental Plans (SDPs), that were designed for reporting on key priorities, crosscutting goals spanning departments and departmental day-to-day business. Oversight bodies observed the lack of a 'cross-government approach to business planning, no clear set of objectives, no coherent set of performance measures and serious concerns about the quality of data that was available' (NAO 2016, 12; CPA 2016). The government claimed nonetheless that these processes added up to a management system. The contrary position was that the 'collection of processes does not amount to the coherent strategic framework for planning and managing public sector activity' (NAO 2016, 7). The SDPs were judged to be potentially a step forward, but their effectiveness remained untested, and they needed further development (CPA 2016). Priorities of departments were 'vague statements of intent or platitudinous aspirations' (PACAC 2018, 16), the link between priorities and resources was tenuous and there remained 'weak incentives to prioritise, make realistic plans and consider long-term value' (NAO 2018, 12).

\section{Other performance instruments}

In addition to the generic performance management framework, each country developed specialised ongoing and ad hoc whole-of-government instruments for pursuing performance. Many efficiency reviews, however, are not subject to public reporting and do not qualify here. ${ }^{1}$

1 Economy exercises may have performance implications. Australian functional reviews were concerned inter alia with the identification of barriers to performance (Cormann 2015). 


\section{Implementation/delivery and monitoring}

Results and government priorities agendas are sometimes reflected in implementation/delivery units (e.g. the UK's Prime Minister's Delivery Unit), and minister-led cross-departmental priorities (such as those resulting from New Zealand's Better Public Services report [BPSAG 2011], and potentially from the UK's cabinet taskforces).

\section{Executive performance}

The development of secretary performance assessment has been an element in the panoply of performance instruments. All Anglophone systems have some form of performance assessment for department heads. Of the four described in this chapter, the Australian arrangement appears to have been less publicly developed. There has been also a possible underlying sanction entailing career prospects other than short-term rewards (Podger 2007).

Canada has had formalised guidelines for deputy ministers in some form since at least the early 2000s. The Privy Council Office's (2018) performance guidelines read prima facie as a compensation plan that includes performance pay. Performance agreements are made between the PCO clerk and the deputy minister for commitments in the results areas of policy and program, management (as specified by MAF), leadership and corporate. New Zealand redefined the relationship between ministers and departmental chief executives appointed on performance agreements. The State Services Commission has been responsible for their performance agreements as a cornerstone of performance management. The commissioner has appointed, employed and reviewed chief executive performance, including the achievement of results and investment in organisational capability (SSC 2006; Scott 2016). Permanent secretary objectives have been used in the United Kingdom for performance management. The objectives of each secretary are agreed with ministers and the prime minister and have been publicly available since 2012 . They are reviewed annually by the civil service head. The objectives have covered priorities such as strategic, business, diversity, leadership and capability, and generic responsibilities: contributing to the corporate leadership of the civil service and supporting civil service reform (Freeguard et al. 2017). 


\section{Organisational capabilities}

A focus on management capability addresses the organisational attributes (e.g. human capital, systems, relationships) required for the performance expected. Capability reviews have been used in Australia and the United Kingdom, and Performance Improvement Frameworks (PIFs) in New Zealand. The Canadian MAF has a capability element. Capability reviews were discontinued in Australia and the United Kingdom; self-assessments have been used in both countries and critiqued in the UK as a poor variant. New Zealand continued to make use of its adapted version, PIFs, which have also had a more explicit performance aspect (School of Government 2017).

\section{Program evaluation}

The use of evaluation has been highly variable in the Anglophone systems, which have not been responsive to renewed international interest in a central role, with one exception. For Australia, evaluation was a crucial element in the 1980s managing for results because it linked policy development and program implementation (Keating and Holmes 1990; Halligan and Power 1992; Di Francesco 1998). Following an experiment with mandatory program evaluation there were over two decades of indifference except for a few departments. The lack of departmental agreement meant nothing emerged, although an independent review supported greater use (Alexander and Thodey 2018). In New Zealand, evaluation has also been essentially a departmental responsibility, and several have had evaluation capacities (Scott 2016). Although, an outcomes approach requires measurement based on evaluation (Hughes and Smart 2012), the use of evaluation for policy advice processes was limited compared to other countries (Scott, Faulkner and Duignan 2010). UK evaluation was at a low ebb prior to 1997 (Talbot 2010). Since then 'some progress' occurred, although doubts existed about whether it produced meaningful learning, and the obstacles to quality evaluation were substantial (Hallsworth, Parker and Rutter 2011; NAO 2010). The exception has been Canada, which has a long history of mandatory evaluation through the Treasury Board Secretariat (Shepherd 2016). All programs were to be reviewed every five years and departments were expected to maintain 'a robust, neutral evaluation function' (TBS 2016). The record with program evaluation was mixed, depicted as being about 'turning a crank that's not attached to anything' (Savoie 2014, 149; Savoie 2011). 


\section{Management Accountability Framework (MAF)}

Canada is unusual in relying on the MAF as an omnibus approach for over two decades. The MAF has entailed a top-down system of monitoring and compliance by the Treasury Board Secretariat. Despite a performance element to the framework, MAF was 'more audit and process-based' (Dean 2009, 31). It has been used to comprehensively assess departmental performance for 10 areas, guided by a framework, 'a high-level model of the attributes of a "well-performing" public sector organisation, but MAF increasingly has the look and feel of a quality assurance and risk management assessment system' (Lindquist 2009, 49, 56). The value of MAF has continued to be hazy (and debated) given the transaction costs. It has provided an instrument for monitoring departmental performance, and MAF results do feed into deputy ministers' assessments (Lindquist 2017), but the regulatory compliance aspect lingers despite modifications over time. MAF is part of an extensive oversight system of instruments, which, according to the auditor general, existed to prevent the Phoenix fiasco but did not (SSCNF 2018).

\section{Corporate performance assessment}

New Zealand has used the annual Administrative and Support Services Benchmarking (BASS) since 2010 for systematising information about corporate services. It has provided agencies with performance information on expenditure on back office services, consistent performance data across agencies and an 'evidence base' for performance assessment. ${ }^{2}$ It was pitched as a benchmarking analysis to assist agencies with achieving efficiencies by using targets. Initial improvements were not sustained, suggesting that the instrument was not driving performance improvement. Systemlevel impacts were modest, and the degree of comparability was unclear (Bonner 2014).

2 For more information, see: www.treasury.govt.nz/statesector/performance/bass. 


\section{Crosscutting program performance}

New Zealand's Better Public Services is arguably the best documented exercise at the subsystem level (Scott and Boyd 2017). The concept of a leadership superstructure overlaying several departments in pursuit of defined objectives is not new (although like other international experiments has not been durable: Peters 2015).

The performance system consists of the core framework and specialised instruments. These performance instruments can be represented as being part of a system. Performance instruments can be designed for distinctive purposes (e.g. accountability to parliament or implementing priorities). However, there is a question as to what extent the centre operates corporately in using levers for modulating and strengthening systemic performance (and there are issues in steering performance systems: Talbot 2008). New Zealand has had a conscious approach to using a range of performance instruments, although the elements in its system of performance were not linked effectively (Allen and Eppel 2017).

\section{Performance frameworks in flux?}

An ever-growing catalogue of weaknesses in performance management was evident by the third decade of the reform era, which have not been resolved by framework development (Bouckaert and Halligan 2008; Radin 2006). These need not be reproduced here beyond noting the most salient and intractable issues. Practice generally fell short of aspirations, and significant questions remained about the quality and use of performance information in the budget process and for internal decisionmaking; questions also remained about the relevance of performance information for external reporting and its political relevance, and about the variable engagement of departments and agencies. The limitations of country approaches included questions about the effectiveness of their frameworks, particularly the tendency towards a compliance emphasis focused on external reporting rather than other objectives. Performance management systems were regularly modified to improve operability, but their effectiveness was undermined by tardiness and reluctance in modifying the framework, and by churn (in the case of the United Kingdom). Common features were disconnects between outputs and outcomes and between internal planning and reporting, and reconciling 
demand and supply of performance information (i.e. what politicians want) (Bouckaert and Halligan 2008; Gill 2011a; Talbot 2010; Edwards et al. 2012; NAO 2016).

\section{Outcomes and outputs}

All management frameworks have featured outputs and outcomes in some form. Both Australia and New Zealand were talking outcomes in the 1980s, but the paths diverged. New Zealand identified outcomes with ministers and outputs with chief executives, with a performance agreement between them. This was perceived in Australia as institutionalising the separation of policy and delivery, a perennial issue in public administration. In contrast, Australia wished to bring them together, but ambiguity, even blurring, remained as to responsibilities (Holmes 1989). In the long term, neither approach was sustained. The outcomes side remained underdeveloped or unresolved, eventually being either assigned to politicians or overshadowed by an output focus. New Zealand's 'managing for outcomes' approach was discontinued because performance measures lacked the rigour of those for outputs (Hughes and Smart 2012). The inclination in New Zealand was to reject outcomes in favour of some form of results, although by the end of the 2010s they were back in favour. Australia eventually opted for outcomes and programs instead of outputs for the 2009-10 budget. Performance management capability in the United Kingdom has been poor with respect to performance measurement for developing 'outcomebased and longer-term indicators' (NAO 2016, 35). UK Treasury has acknowledged the challenge of moving from inputs to outputs to outcomes, and inputs have continued to be a focus reflecting the central agency's role in public spending and because manifestos have focused on levels of expenditure (CPA 2018, Q23).

\section{Quality of performance information}

Issues with performance information have long been raised by auditor generals in all four countries with two recent examples being noted here. UK oversight agencies, like counterparts elsewhere, have long had issues with the quality of performance information. Insufficient information was provided 'to hold departments to account for all costs, outcomes and value for money on both the coalition agreement and across all of a department's work' (NAO 2016, 24; CPA 2011). The Committee of Public Accounts found no improvements, concluding that accountability 
officers lacked the cost and performance data required for undertaking effective oversight. This was regarded as a long-standing problem, as the National Audit Office had previously reported that 'variation in the scope and completeness of information currently available limited its ability to inform public choice and accountability' (NAO 2016, 24). The Canada Revenue Agency misrepresented its performance in dealing with taxpayers: 'Too often ... performance measures do not reflect the actual performance' (SSCNF 2018; OAG 2017).

\section{Decoupling of functions}

The decoupling of functions - outcomes and outputs - from operational practice (Dormer and Gill 2010) was a commonplace response to central performance management systems. The frontline may be either disengaged from the senior management's preoccupation with outputs and outcomes that was expected at the whole-of-government level, or reflective of departmental operating principles.

Australian departments went through the routine of producing the material for reporting purposes but were inclined to rely on their own internal planning for operational matters under the second model, while the third framework sought to integrate performance and internal corporate reports. One dimension was organisational incentives. The performance framework did not require departments to integrate their own internal planning processes, with the performance process, which was an external imposition. Consequently, the two processes were run in parallel. Priority was given to external reporting, while performance information was not generally made use of for internal purposes. Since the incentives didn't exist for departments to apply the framework for their own purposes, there was insufficient attention given to organisational culture, and the embedding of performance. The inclination of departments to deviate from performance management frameworks has been long argued by the Australian National Audit Office (Bouckaert and Halligan 2008; McPhee 2005).

\section{Targetism}

The use of targets has been commonplace but pursued with particular zeal in the UK. The fixation on targetism under Blair extended from the composition of PSAs with departments, mainly defined in terms of outputs and outcomes, to delivery organisations operating under tough 
sanctions for missing targets, such as threats of job loss, agency termination and publicity on results (Flynn 2007). In New Zealand, achieving results through targets became simply another control function (Gill 2011a).

Performance in Canada became:

the product of many hands, from the political level down to the most junior front-line worker. There was no incentive for public servants to draw attention to problems, to explain what has gone wrong, or to suggest why performance targets may not be realistic. (Savoie 2011, 160)

Savoie quotes Michael Warnick (then deputy minister and later a clerk of the PCO) who reported that departments dealt with central agency demands by producing 'fake stuff, which is 'the stuff you pretend to do that you feed to the central agencies to get them off your back' (Savoie 2011, 160).

\section{Use of information}

Who uses performance information and why is it not used (Van Dooren, Bouckaert and Halligan 2015)? A range of factors have contributed to the mixed use of performance information (e.g. the standard problems with devising indicators for outcomes), the organisational-level performance gaps derived in the first instance from the design and implementation of the framework, and the inability of political and public service leadership to respond to the weaknesses. This situation can be argued to be a consequence of a combination of a new public management-type solution and a political nexus that is diffident about the role of central leadership in performance management.

Pollitt (2006) pointed out that research has rarely focused on the 'end users' of performance information in the traditional model of representative democracy - that is, ministers, parliamentarians and citizens - and that if they used performance information it would, 'constitute the definitive justification for the practices of evaluation, performance management and performance audit as components of a democratic polity, rather than as merely an artefact of technocratic administration' (38).

More generally, the use of performance information to underpin budgeting has long been an unfulfilled objective, although it may inform aspects (Cangiano et al. 2013). 


\section{Renewal through planning and priorities?}

The four systems described have followed different pathways within a performance management framework. Their early implementation styles differed in terms of conceptions of the relationship between outputs and outcomes, the responsibilities given to chief executives, and the roles of the central personnel agency in handling performance oversight. There continue to be differences in approach and with the treatment of outcomes and outputs. Several generations of performance management provided extensive experience of potential limitations. The management discipline, efficiencies and accountabilities achieved under these frameworks sustain commitment and the quest for system improvements in managing performance.

Three of the frameworks have undergone recent transformations: Australia's third framework formally incorporates business planning and Canada's two-level results focus combines the revised performance management framework of the TBS with a political overlay for driving the focus through the PCO. The UK approach has had the most discontinuity and its poor public articulation has been ambitious and multipurpose. In the case of New Zealand, the inability to move from an entrenched focus on output accountability, which served the system well for efficiency purposes, left the framework otherwise unserviceable (Morrison 2014; NAO 2016; Gold 2017). For some time, results replaced the language of outcomes, and were 'effectively bite-sized pieces of an outcome (similar to what were previously called intermediate outcomes)'. The government wanted 'tangible progress towards its larger objectives, which in effect was a renaming of outcome indicators' (Morrison 2014, 47). A switch back to outcomes has occurred under the Arden Government.

The dissatisfaction with obtaining results through outputs and outcomes had not led to a focus on results instead of outcomes. The knitting together of performance with planning and/or priorities caters for different purposes. The expansion of purposes means that distinctions could be made between keeping to the basics and more comprehensive schemes.

The later part of the 2010s has been a time of evolution and experiments with frameworks in all four countries, with the level of change and other details not necessarily yet publicly available. With that caveat in mind, several dimensions are distinguished in Table 5.1. In terms of purposes, all systems provide for formal accountability, and usually some measure 
of internal department planning, with the level of central control variable. Results are more formally recognised in two countries for the whole-ofgovernment framework.

Table 5.1. Dimensions of frameworks

\begin{tabular}{|l|l|l|l|l|}
\hline & Australia & Canada & New Zealand & United Kingdom \\
\hline 1.Purposes & Focused & Multiple & Focused & Comprehensive \\
\hline Accountability* & Formal & Formal & Formal & Formal \\
\hline Planning & Yes & Yes & Yes & Yes \\
\hline Priorities & In development & Evolving & $\begin{array}{l}\text { In selected } \\
\text { areas }\end{array}$ & Still evolving \\
\hline 2. Stakeholders & Focused & Focused & Focused & Broad in concept \\
\hline 3.Stability & $\begin{array}{l}\text { Yes, but } \\
\text { evolving }\end{array}$ & $\begin{array}{l}\text { Yes, overlay } \\
\text { effects unclear }\end{array}$ & $\begin{array}{l}\text { Yes, but } \\
\text { evolving }\end{array}$ & $\begin{array}{l}\text { Changeable } \\
\text { in 2010s }\end{array}$ \\
\hline $\begin{array}{l}\text { Continuity across } \\
\text { governments }\end{array}$ & Yes & $\begin{array}{l}\text { Yes, but } \\
\text { augmented }\end{array}$ & Yes & No \\
\hline $\begin{array}{l}\text { 4. Cross- } \\
\text { government }\end{array}$ & $\begin{array}{l}\text { Available, } \\
\text { unused }\end{array}$ & Unclear & $\begin{array}{l}\text { Recent } \\
\text { experience }\end{array}$ & $\begin{array}{l}\text { Unfulfilled in latest } \\
\text { iteration }\end{array}$ \\
\hline 5. Evaluation & $\begin{array}{l}\text { Left to } \\
\text { departments }\end{array}$ & Central role & $\begin{array}{l}\text { Left to } \\
\text { departments }\end{array}$ & $\begin{array}{l}\text { Left to } \\
\text { departments }\end{array}$ \\
\hline
\end{tabular}

* Relatively unused in practice.

Source: Author's summary.

Framework stability and continuity across governments have been apparent in three cases, the exception being the United Kingdom. Attention to fundamentals for planning, managing and changing priorities has been lacking in the UK's SDP framework:

Government needs a proper framework for planning to the medium term and beyond, that will allow it to make achievable plans, and to understand what it needs to know to stay on track. This framework should be stable and enduring, existing independent of political priorities. (NAO 2016, 6)

The stakeholder approach was generally focused, but the United Kingdom's aspirations were more broadly conceived. The SDP framework was designed by the Cabinet Office and Treasury:

to cover a large number of different stakeholders' needs, by capturing for the first time the whole range of departments' aims and objectives including departmental commitments, cross-department goals, day-to-day service delivery, business transformation programmes and efficiency improvements. (NAO 2016, 14) 
It was subsequently judged to require a range of changes, without which 'government will continue to be trapped in a cycle of short-termism, overoptimism and silo decision-making, which creates real risks to value for money' (NAO 2018, 13).

The interest of political executives in results and priorities has varied between countries. It has also been underpinned by the strong role of the prime minister's department in performance management in two jurisdictions (e.g. the Canadian Privy Council Office and the UK Cabinet Office). The others are active in cross-government activity. Evaluation was mainly a matter for departments.

\section{Conclusion}

Bearing in mind the introductory questions, how has this uneven record been worked through? Performance management frameworks have neither gelled nor become durable as multipurpose fixtures. The 2010s have been a decade of experimentation with instruments for performance improvement. What form of performance is appropriate is not amenable to a consistent answer beyond the basic requirement of satisfying a public accounting for results against objectives. In responding to multiple objectives and stakeholder expectations, two polar options are to rely either on an omnibus document (more like the UK) or several instruments (New Zealand). The purposes of performance management remain unresolved, particularly where it is subject to turnover with governments.

The place of 'results' in the overall scheme of things remains a conundrum. Performance has become more focused on achieving political agendas. The framework is likely these days to be skewed in that direction rather than serving the needs of either departments or the public, although the former is catered for if the renewed emphasis on business planning works. However, inflexibilities are still present, and the cross-departmental aspect problematic.

Have the four countries discussed in this chapter devised stable performance instruments to provide the information expected by stakeholders? One has persisted with progressive iterations of a core framework (Australia). Two have worked around limitations with the framework overlaying a results reporting facility (Canada and the United Kingdom) while New Zealand now accords centrality to its wellbeing budget (New Zealand). 
The United Kingdom has opted for regularly replacing the framework, and while its ambitious 'road map' remains unrealised, if successful, it will potentially provide a new model. To what extent a performance system exists is dependent on design questions and the attention given by a corporate centre to systemic questions and impacts of performance.

There have been long-term difficulties with engaging effectively with a performance approach. Frameworks take time to develop and implement and perennial issues continue to resurface. All systems are working through new arrangements, the results of which remain unclear. What is apparent is that the performance story is still in progress after over three decades and, without resolution of chronic issues, will remain a contested area.

\section{References}

Alexander, E. and D. Thodey. 2018. Independent Review into the Operation of the Public Governance, Performance and Accountability Act 2013 and Rule. Canberra: Commonwealth of Australia.

Allen, B. and E. Eppel. 2017. 'The New Zealand performance improvement framework - Strategic conversation, organisational learning or compliance tool?' Paper presented at IRSPM Conference, Budapest, 19-21 April.

Australian National Audit Office (ANAO). 2011. Development and Implementation of Key Performance Indicators to Support the Outcomes and Programs Framework. Auditor-General Report No. 5 of 2011-12. Canberra: Commonwealth of Australia.

Australian National Audit Office (ANAO). 2013. The Australian Government Performance Measurement and Reporting Framework: Pilot Project to Audit Key Performance Indicators. Auditor-General Report No. 28 of 2012-13. Canberra: Commonwealth of Australia.

Behn, R. D. 2003. 'Why measure performance? Different purposes require different measures'. Public Administration Review 63(5): 586-606. doi.org/ 10.1111/1540-6210.00322.

Better Public Services Advisory Group NZ (BPSAG). 2011. Better Public Services: Advisory Group Report. Wellington: New Zealand Government. doi.org/ 10.26686/pq.v8i3.4422.

Bonner, S. 2014. 'Performance management in the New Zealand public sector'. Business research project for MBA. Wellington: Victoria University of Wellington. 
Boston, J., J. Martin, J. Pallot and P. Walsh. 1996. Public Management: The New Zealand Model. Auckland: Oxford University Press.

Bouckaert, G. and J. Halligan. 2008. Managing Performance: International Comparisons. London: Routledge.

Bull, D., J. Stephen, P. Bouchal and G. Freeguard. 2013. Whitehall Monitor: No. 41: How Departments Measure their Performance. London: Institute for Government.

Campbell, C. and J. Halligan. 1992. Political Leadership in an Age of Constraint: The Experience of Australia. Sydney: Allen \& Unwin and Pittsburgh: University of Pittsburgh Press.

Cangiano, M., T. Curristine and M. Lazare (eds). 2013. Public Financial Management and Its Emerging Architecture. Washington DC: International Monetary Fund.

Clark, I. D. and H. Swain. 2005. 'Distinguishing the Real from the Surreal in Management Reform: Suggestions for Beleaguered Administrators in the Government of Canada'. Canadian Public Administration 48(4): 453-477. doi.org/10.1111/j.1754-7121.2005.tb01198.x.

Committee of Public Accounts UK (CPA). 2011. Accountability for Public Money. 28th report of session 2010-11. HC 740. London: House of Commons.

Committee of Public Accounts UK (CPA). 2016. Managing Government Spending and Expenditure. 27th report of session 2016-17. HC 710. London: House of Commons.

Committee of Public Accounts UK (CPA). 2018. Driving Value in Public Spending: Oral Evidence. 78th report of session 2017-19. HC 1596. London: House of Commons.

Controller and Auditor-General (CAG) 2006. Central Government Results of the 2004-2005 Audits. Parliamentary Paper. Wellington: Office of the Auditor General.

Cormann, M. 2015. Smaller and More Rational Government 2014-15. Ministerial Paper. Canberra: Commonwealth of Australia.

Dean, T. 2009. UK Public Service Reforms: A Canadian Perspective. Toronto: Institute of Public Administration of Canada.

Department of Finance (DoF). 2014. Enhanced Commonwealth Performance Framework: Discussion Paper. Canberra: Commonwealth of Australia. 
Department of Finance (DoF). 2015. Findings Report on the July PGPA Benefits Realisation Survey. Canberra: Commonwealth of Australia.

Department of Finance and Deregulation (DFD). 2012. Sharpening the Focus: A Framework for Improving Commonwealth Performance. Canberra: Commonwealth of Australia.

Di Francesco, M. 1998. 'The measure of policy? Evaluating the evaluation strategy as an instrument for budgetary control'. Australian Journal of Public Administration 57(1): 33-48. doi.org/10.1111/j.1467-8500.1998.tb01362.x.

Dormer, R. and D. Gill. 2010. 'Managing for performance in New Zealand's public service - A loosely coupled framework?' Measuring Business Excellence 14(1): 43-59. doi.org/10.1108/13683041011027445.

Edwards, M., J. Halligan, B. Horrigan and G. Nicoll. 2012. Public Sector Governance in Australia. Canberra: ANU Press. doi.org/10.22459/psga.07.2012.

Flynn, N. 2007. Public Sector Management. 6th edition. London: Sage.

Freeguard, G., R. Adam, E. Andrews and A. Boon. 2017. Whitehall Monitor 2017: The Civil Service as it Faces Brexit. London: Institute for Government.

Gill, D. (ed.). 2011a. The Iron Cage Recreated: The Performance Management of State Organisations in New Zealand. Wellington: Institute of Policy Studies.

Gill, D. 2011b. 'Introduction'. In D. Gill (ed.) The Iron Cage Recreated: The Performance Management of State Organisations in New Zealand. Wellington: Institute of Policy Studies.

Gill, D. and T. Schmidt. 2011. 'Organisational performance management: Concepts and themes'. In D. Gill (ed.) The Iron Cage Recreated: The Performance Management of State Organisations in New Zealand. Wellington: Institute of Policy Studies.

Gold, J. 2017. Tracking Delivery: Global Trends and Warning Signs in Delivery Units. London: Institute for Government.

Halligan, J. 2007a. 'Reintegrating government in third generation reforms of Australia and New Zealand'. Public Policy and Administration 22(2): 217-238. doi.org/10.1177/0952076707075899.

Halligan, J. 2007b. 'Performance management and budgeting in Australia and New Zealand'. In P. de Lancer Julnes, F. Berry, M. Aristigueta and K. Yang (eds) International Handbook of Practice-Based Performance Management. Thousand Oaks, California: Sage. doi.org/10.4135/9781412982719.n17. 
Halligan, J. 2020. Reforming Public Management and Governance: Impacts and Lessons from Anglophone Countries. Cheltenham, UK: Edward Elgar.

Halligan, J. and J. Power. 1992. Political Management in the 1990s. Melbourne: Oxford University Press.

Hallsworth, M., S. Parker and J. Rutter. 2011. Policymaking in the Real World: Evidence and Analysis. London: Institute for Government.

Hawke, L. 2012. 'Australian public sector performance management: Success or stagnation?' International Journal of Productivity and Performance Management 61(3): 310-328. doi.org/10.1108/17410401211205669.

Hawke, L. 2016. 'Australia'. In D. Moynihan and I. Beazley (eds) Towards Next-Generation Performance Budgeting: Lessons from the Experience of Seven Reforming Countries. Washington DC: The World Bank. doi.org/10.1596/ 978-1-4648-0954-5_ch5.

Hawke, L. and J. Wanna. 2010. 'Australia after budgetary reform: A lapsed pioneer or decorative architect?' In J. Wanna, L. Jensen and J. de Vires (eds) The Reality of Budgetary Reform in OECD Countries: Trajectories and Consequences. Cheltenham, UK: Edward Elgar. doi.org/10.4337/97818498 05636.00010 .

Holmes, M. 1989. 'Corporate management: A view from the centre'. In G. Davis, P. Weller and C. Lewis (eds) Corporate Management in Australian Government. Melbourne: Macmillan.

Hughes, P. and J. Smart. 2012. 'You say you want a revolution ... The next stage of public sector reform in New Zealand'. Policy Quarterly 8(1): 3-16. doi.org/ 10.26686/pq.v8i1.4408.

Institute for Government UK. 2011. 'Business plans: A long way to go'. Press release. 11 July. Available at: www.instituteforgovernment.org.uk/news/latest /business-plans-long-way-go.

Institute for Government UK. 2012. 'Government business plans fail to live up to expectations'. Press release. 20 November. Available at: www.institute forgovernment.org.uk/news/latest/government-business-plans-fail-liveexpectations.

James, C. 2019. "'Wellbeing"' facet points to different way of governing'. Otago Daily Times, 31 May, 8.

James, O. 2004. 'The UK core executive's use of public service agreements as a tool of governance'. Public Administration 82(2): 397-419. doi.org/10.1111/ j.0033-3298.2004.00400.x. 
Keating, M. and M. Holmes. 1990. 'Australia's budgetary and financial management reforms'. Governance 3(2): 168-185. doi.org/10.1111/j.1468-0491.1990. tb00113.x.

Kibblewhite, A. and C. Ussher. 2002. 'Outcome-focused management in New Zealand'. Journal of Budgeting 1(4): 85-109. doi.org/10.1787/budgetv1-art23-en.

Lindquist, E. 2009. 'How Ottawa assesses department/agency performance: Treasury Board's management accountability framework'. In A. M. Maslove (ed.) How Ottawa Spends 2009-2010: Economic Upheaval and Political Dysfunction. Montreal and Kingston: McGill-Queen's University Press.

Lindquist, E. 2017. 'Rethinking the management accountability framework for the open government era'. In K. Graham and A. Maslove (eds) How Ottawa Spends 2017-2018: Canada @150. Ottawa: School of Public Policy and Administration, Carleton University.

Mackay, K. 2004. Two Generations of Performance Evaluation and Management Systems in Australia. ECD Working Paper Series 11. Washington DC: World Bank.

Mackay, K. 2011. 'The performance framework of the Australian Government, 1987 to 2011'. OECD Journal on Budgeting 11(3): 75-122.

McPhee, I. 2005. 'Outcomes and outputs: Are we managing better as a result?' Paper presented at CPA National Public Sector Convention, Melbourne, 20 May.

Morrison, A. 2014. 'Picking up the pace in public services'. Policy Quarterly 10(2): 43-48.

National Audit Office UK (NAO). 2010. Evaluation in Government. London: National Audit Office.

National Audit Office UK (NAO). 2016. Government's Management of its Performance: Progress with Single Department Plans. HC 872. Session 2016-17. London: National Audit Office.

National Audit Office UK (NAO). 2018. Improving Government's Planning and Spending Framework. HC 1679. Session 2017-19. London: National Audit Office.

Office of the Auditor General of Canada (OAG). 2017. Report 1 - Phoenix Pay Problems. 2017 Fall Reports: Report 1. Ottawa: Auditor General of Canada. 
Organisation for Economic Cooperation and Development (OECD). 1995. Governance in Transition: Public Management Reforms in OECD Countries. Paris: OECD Publishing.

Panchamia, N. and P. Thomas. 2014. Civil Service Reform in the Real World: Patterns of Success in UK Civil Service Reform. London: Institute for Government.

Peters, B.G. 2015. Pursuing Horizontal Coordination: The Politics of Public Sector Coordination. Lawrence: University of Kansas Press.

Podger, A. 2007. 'What really happens: Departmental secretary appointments, contracts and performance pay in the Australian Public Service'. Australian Journal of Public Administration 66(2): 131-147.

Podger, A. 2015. 'Further development of Australia's performance management system: Emphasising "how" and "why" as well as "what". Paper presented at 2015 AGPA Conference, Seoul, September.

Pollitt, C. 2006. 'Performance information for democracy: The missing link?' Evaluation 12(1): 38-55.

Pollitt, C. 2013. 'The logics of performance management'. Evaluation 19(4): 346-363.

Privy Council Office of Canada. 2018. 'Performance management program for deputy ministers, associate deputy ministers and individuals paid in the GX range'. Government of Canada. Available at: www.canada.ca/en/ privy-council/programs/appointments/governor-council-appointments/ performance-management/senior-public-servants.html.

Public Administration and Constitutional Affairs Committee, House of Commons UK (PACAC). 2018. The Minister and the Official: The Fulcrum of Whitehall Effectiveness. 5th report of session 2017-19. HC 497. London: House of Commons.

Radin, B. 2006. Challenging the Performance Movement: Accountability, Complexity, and Democratic Values. Washington, DC: Georgetown University Press.

Savoie, D. J. 2011. 'Steering from the centre: The Canadian way'. In K. Dahlström, B. G. Peters and J. Pierre (eds) Steering from the Centre: Strengthening Political Control in Western Democracies. Toronto: University of Toronto Press. doi.org/ 10.3138/9781442687066-009.

Savoie, D. J. 2014. Whatever Happened to the Music Teacher? How Government Decides and Why. Montreal and Kingston: McGill-Queen's University Press. 
Schick, A. 1996. The Spirit of Reform: Managing the New Zealand State Sector in a Time of Change. Report prepared for the State Services Commission and the Treasury. Wellington: New Zealand Public Service Commission.

Schick, A. 2001. Reflections on the New Zealand Model. Based on a lecture at New Zealand Treasury, August.

School of Government. 2017. Independent Review of the Performance Management Framework. Wellington: School of Government, Victoria University of Wellington.

Scott, G. 1997. 'Continuity and change in public management: Second generation issues in roles, responsibilities and relationships'. In State Services Commission, Future Issues in Public Management. Wellington: State Services Commission.

Scott, G. 2001. Public Management in New Zealand: Lessons and Challenges. Wellington: New Zealand Business Roundtable.

Scott, G., P. Faulkner and P. Duignan. 2010. Improving the Quality and Value of Policy Advice. Review of expenditure on policy advice. Wellington: Government of New Zealand. Available at: treasury.govt.nz/sites/default/files/2011-04/ report-repa-dec10.pdf.

Scott, R. 2016. Theoretical Foundations of Department Chief Executive Performance Appraisals. Working Paper 2016-4. Wellington: State Sector Performance Hub.

Scott, R. and R. Boyd. 2017. Interagency Performance Targets: A Case Study of New Zealand's Results Programme. Washington, DC: IBM Centre for the Business of Government.

Shand, D. and R. Norman. 2005. 'Performance budgeting in New Zealand'. Paper prepared for IMF Fiscal Affairs Department Seminar on Performance Budgeting, Washington DC, 5-7 December.

Shepherd, R. P. 2016. 'The program evaluation function: Uncertain governance and effects'. In T. Klassen, D. Cepiku and T. J. Lah (eds) The Routledge Handbook of Global Public Policy and Administration. New York: Routledge.

Standing Senate Committee on National Finance (SSCNF). 2018. Proceedings of the Standing Senate Committee on National Finance: Issue No. 70, Evidence. Ottawa, 12 June.

State Services Commission (SSC). 2006. 'The Role of the State Services Commissioner'. Public Service Commission. Available at: www.publicservice. govt.nz/about-us/sscer. 
Stephen, J., R. Martin and D. Atkinson. 2011. See-Through Whitehall: Departmental Business Plans One Year On. London: Institute for Government.

Talbot, C. 2008. 'Performance regimes - The institutional context of performance policies'. International Journal of Public Administration 31(14): 1569-1591. doi.org/10.1080/01900690802199437.

Talbot, C. 2010. Performance in Government: The Evolving System of Performance and Evaluation Measurement, Monitoring, and Management in the United Kingdom. ECD Working Paper Series No. 24. Washington DC: World Bank.

Tanner, L. 2008. Operation Sunlight: Enhancing Budget Transparency. Canberra: Australian Government.

Task Force on Management Improvement (TFMI). 1993. The Australian Public Service Reformed: An Evaluation of a Decade of Management Reform. Canberra: Commonwealth of Australia.

Thomas, P. 2004. Performance Measurement, Reporting and Accountability: Recent Trends and Future Directions, Public Policy Paper 23. Regina: The Saskatchewan Institute of Public Policy.

Treasury of Canada Board Secretariat, Internal Audit and Evaluation Bureau (TBS). 2016. 'Evaluation of the management accountability framework'. 16 December. Available at: www.canada.ca/en/treasury-board-secretariat/ corporate/reports/evaluation-management-accountability-framework.html.

Van Dooren, W., G. Bouckaert and J. Halligan. 2015. Performance Management in the Public Sector. Second edition. London: Routledge. doi.org/10.4324/ 9781315817590 .

Wanna, J., J. Kelly and J. Forster. 2000. Managing Public Expenditure in Australia. Sydney: Allen \& Unwin. 
This text is taken from Politics, Policy and Public Administration in Theory and Practice: Essays in Honour of Professor John Wanna, edited by Andrew Podger, Michael de Percy and Sam Vincent, published 2021 by ANU Press, The Australian National University, Canberra, Australia.

doi.org/10.22459/PPPATP.2021.05 